\title{
Figures of Speech on Political Headline: Waspada and Sinar Indonesia Baru (SIB) Newspaper
}

\author{
Ade Nurfitriani Harahap ${ }^{1, *}$ I Wy Dirgeyasa ${ }^{2}$ Anni Holila Pulungan ${ }^{3}$ \\ ${ }^{1,2,3}$ Post Graduate School of Applied Linguistics Study Program, Universitas Negeri Medan, Jl. Willem Iskandar, \\ Medan, Indonesia. \\ "Corresponding author. Email: adefitrihrp@gmail.com
}

\begin{abstract}
This study dealt with figures of speech in political headline: Waspada and Sinar Indonesia Baru (SIB) Newspaper. This research used a qualitative research design with a single case study to gain an understanding on this study. It was conducted descriptively. Figures of speech is a departure from the usual form of expression for the purpose of making the meaning clearer, more forceful, or more beautiful. The objective of the study was to investigate the types of figures of speech in political headline: Waspada and Sinar Indonesia Baru (SIB) Newspaper. The data were utterances and word of political headline and source of data taken from online newspaper. The result of the data showed that there were five types of twelve of figures of speech in Waspada and Sinar Indonesia Baru (SIB) Newspaper. In Waspada there were four types of figures of speech namely personification, symbol, paradox, and irony. Meanwhile, in Sinar Indonesia Baru (SIB) there were three types of figures of speech namely personification, apostrophe, and symbol. The findings showed that symbol was the most frequently used figures of speech in both newspapers. The figures of speech used in all situations that show expression in which the name of an attribute or based on the ideology each the both newspapers are different so it could be concluded that the figures of speech in both newspapers adopted the similar style of language and way of approaching the issues politic by making use of figures of speech.
\end{abstract}

Keywords: Figures of Speech, Types of Figures of Speech, Waspada and Sinar Indonesia Baru Newspaper.

\section{INTRODUCTION}

Language is very important in human life. It is a means of communication between individuals and has become social phenomenon. It also brings them into relationship with their environment. Language is therefore socially learned behavior, a skill that is acquired as we grow up in society. Language is a means that is used for communicating with other people in society. The language in use for communication is called discourse. It can be said that all forms of language in use to communicate among people are named 'discourse'. It is the relation between languages at the context in which it is used.

Media of communication are also more varied in their development, for example, printed media, electronic media, and mass media. There are various forms of mass media in the era of information and communication like printed as well as electronic media [12]. The printed media has its own unique features and the influence on its readers as it is available on the hands of the readers.

The media especially the newspaper is an important institution in every society [13]. Whichever roles or functions it plays at a particular time matters a great deal. A particular news or feature story, editorial comments, personal commentary that is published in a newspaper could play multiplicity of roles. It could serve as a platform to access information on the item of the news published; it could serve as a minor or a reflection of the social reality of the item published; it could have elements or ingredient of discernment that accelerates understanding of the news published. All of these could be combined in one way or the other to affect the level of understanding, knowledge, attitudes and actions of the reading public in determining the course, shape or effect of an event, action or situation.

Here the researcher will explain about the background from Waspada Newspaper. Waspada is an Indonesian daily newspaper published in Medan, North Sumatra by PT. Penerbitan Harian Waspada. Having first published on 11 January 1947, it is the second oldest continuously published newspaper in Indonesia, only behind Kedaulatan Rakyat. It is one of the largest newspapers in the city. In this modern era, the people are very spoiled by technology, with the advent of the internet that the people's lifestyle in the world has 
changed. Without realizing it, in this modern era now everything has surge people's lives, one of which are online news, online job registration, online college registration and so on. Everything is completely online. How could be, in this era many people who regard that technology as their milord, whereas the humans who construct technology.

Just imagine it printed media edition no more published, indeed the tradition of reading newspaper as a whole will disappear. People in Indonesia themselves also need local news information compared to international news. In view of that in general Indonesia society are still developing society. Consequently, print media are required to be creative in order to last longer. One of still be upright up to now is Daily Waspada.

Headlines are usually written in a sensational way in order to arouse the readers' curiosity. As headline writers try to catch the readers' eye by using as few words as possible. Headlinese is the language of headlines which is affected by the constrains on space. It can be said that this writing style of headlines that includes as minimum word as possible and has the specific writing style is called headlinese [10].

Sinar Indonesia Baru (News Indonesia Raya, also known by its abbreviation SIB) is an Indonesia daily newspaper published in Medan, North Sumatera. The newspaper was founded on 9 May 1970 by GM Panggabean a former contributor at Waspada, it claims itself as the only newspaper founded by a Bataknese. Besides printed edition, Sinar Indonesia Baru also maintain its online presence.

Whenever a newspaper is read, the first thing to be noticed is a headline. Firstly, the readers note the headlines of the article and only after then decide whether to read or not. Therefore, the headlines are one of the most important components of the piece of writing. A newspaper headline is often the only thing that readers read in a newspaper, or at least, it is the first thing that everyone notices in a newspaper [12]. It serves as a guide for the reader that helps to decide whether to continue on reading the whole report or skip onto another one. So, headline is the key aspects of the newspaper to attract the readers' attention.

Figurative language is a broad category that includes figures of speech as well as sound devices and imagery. Figures of speech are words or groups of words that must be taken in a non-literal sense in order to understand their meaning. example of figures of speech are similes, metaphors, irony, synecdoche, allusions, puns, hyperbole, understatement and personification. All of these use words in a non-literal or figurative way.

There are some of figures of speech can be found in political headline in newspaper as the preliminary the data. Not all the political headline are easily understandable, especially when the headline not found of figures of speech or figurative language in the words or phrases which hidden meaning inside them. Here are some examples of the figures of speech found in political headline from Waspada newspaper:

\section{a. Di Depan Komisi III, Alexander Marwata: Hanya Orang} Goblok yang Kena OTT KPK

The utterances above included in the types of figures of speech that is irony based on Perrine's theory. Irony is often confused with satire and sarcasm, but it can be used with either a satirical or sarcastic intent [10]. Meanwhile, the function of this utterances included is to add emotional intensity. Figures of speech are a way of adding emotional intensity to otherwise merely informative statement [15]. They also convey attitudes along with the information.

A stylistic analysis of Abdu's stand-up comedy. Her study showed that figures of speech that found in three samples of stand-up comedy material entitled Jaya Indonesia, Orasi dari timur, and Nonton Sinetron Ala Mama are metaphor, simile, personification, synecdoche, metonymy, allegory, hyperbole, paradox, and irony. The contribution of Khairani's research results is a stylistic theory, focused on the types of figurative languages [7].

The problem can be stated implicitly: What types figures of speech on political headline: Waspada and Sinar Indonesia Baru (SIB) Newspaper?

Based on the statement of the problem, the researcher determines the objective of the research is to investigate the types figures of speech on political headline: Waspada and Sinar Indonesia Baru (SIB) Newspaper.

\subsection{Figures of Speech}

Figures of speech is speech are words or group words that must be taken in a non-literal sense in order to understand their meaning. Figures of speech introduces an ambiguity between literal and figurative interpretation. Thus, when having to understand it people have to think deeply. The statement occurred when people are looking at figurative language obviously has an ambiguity meaning in it. It is supported by [4] "a figures of speech in which a name or descriptive word or phrase in transferred to an object or action".

Figures of speech should not be taken literally only. It is because figures of speech make the speaker express something in a non-ordinary way [15]. The purpose of figures of speech is to give another meaning into one thing being said. A figure of speech is a way of saying something other than the literal way. It adds extra dimensions to language and reveals one thing by relating it to something else. Figures of speech is used to describe an object, person, or situation by comparing it with something else [3].

Figurative devices or figures of speech refer to the mode of expression in which words are employed to connote something other than the literal or conceptual meaning. Figures of speech normally add beauty, emotional sensitivity or transfer the author's impression or thought through comparing or identifying a person or a thing with another one that has a meaning which the reader is familiar with. 


\subsubsection{Metaphor}

Metaphor is a comparison between things which essentially unlike. Metaphor as a process of mapping between two different conceptual domains that are known as the source domain (the topic or concept that a speaker or writer draws in order to create the metaphorical construction) and target domain (the topic or concept that a speaker or writer wants to describe) [20]. The analogizing sense in figures of speech can be revealed through metaphor. Implicitly, metaphor is a kind of analogy or comparison. Metaphor can function as subject, object, etc. The form used as metaphor is brief, for example, the sentence He had a heart of lion. This expression means that the subject he had a heart which is strong and brave like a lion [9].

\subsubsection{Simile}

A simile is a figure of speech which makes an explicit relation between two concepts by using 'is like' formula. For example, she is like my sunshine uses the word like to make a connection between the words she and my sunshine and to illustrate that there is a similarity between them, i.e., the value of beauty [20].

\subsubsection{Personification}

Personification gives human being attributes to an animal, an object, or an idea. Those animals, un-living things, or ideas can perform actions like human. For example, Bad weather halts Trigona plane search in Papua (The Jakarta Post) uses the word halts as a verb. Bad weather itself is non-human which is given a human being attribute [15].

\subsubsection{Apostrophe}

Apostrophe is a direct address to someone or something such as an inanimate object, a dead or absent person, an abstract thing, or a spirit. For example, Bright star, would I be steadfast as thou art (John Keats, "Bright Star"), the speaker talks to the bright star that could not answer the speaker's utterance [5].

\subsubsection{Metonymy}

Metonymy is very similar to synecdoche, but instead of a part representing the whole, a related object is used to represent the whole. It uses something more generally or loosely associated with a concept to stand in for it. For example: The king's guns were aimed at the enemy, using guns to represent infantry [15].

\subsubsection{Symbol}

Symbol is a person, place, or thing in a narrative that suggests meanings beyond its literal sense. For example: Ah Sunflower, weary of time, who countess the steps of the sun; Seeking after that sweet golden clime Where the traveller's journey is done; in William Blake's poem entitled "Ah Sunflower", the word sunflower is a symbol that refers to life cycle [5].

\subsubsection{Synecdoche}

Synecdoche is a figurative language that uses parts to represent the whole of something (pars pro toto) or the whole to refer to some of its parts (totem pro parte). For example, each head should contribute money with the nominal predetermined, the word head is a synecdoche which represents a person [6].

\subsubsection{Allegory}

Allegory is a figure of speech in narrative form in verse or prose which the literal events such as persons, places, and things consistently point to a parallel sequence of symbolic ideas. For example, Andy goes with the children. The first meaning of the sentence is Andy goes with his own children, and the second meaning is Andy goes with the children but not his own children [5].

\subsubsection{Paradox}

Paradox is a statement that at first seems as selfcontradictory but it reveals some deeper sense on reflection. In general, paradox may be either a situation or a statement. For example, your enemy is sometimes your close friend. Your friend is sometimes your real enemy tell that in reality, sometimes people cannot recognize what is actually called a friend or an enemy. The sentences make sense semantically. People who can understand paradox well will see something at first impossible is actually possible and contains truth [5].

\subsubsection{Hyperbole}

Overstatement or hyperbole is an exaggeration that is used to emphasize something. For example, the sentence the death of him suddenly makes the entire world stunned stop is used hyperbole or overstatement because it is impossible that by the death of a person, the entire world is being stunned stop [5].

\subsubsection{Litotes}

Understatement as an ironic figure of speech that describes something in a way that is less than the true situation. In understatement or litotes, the speaker does not exaggerate what he/she says. The speaker says the thing ordinarily but states less than the truth. For example, He had a brain cancer but it's OK because he would have an operation. It is not so serious contain litotes or understatement that describe the condition although the subject he had a brain cancer, it follows with but it's OK because he would have an operation and it is not so serious that make the situation less stressful [5]. 


\subsubsection{Irony}

Irony is the opposite of what one means. Irony is a hint that wants to say something with other meaning on what it contains in the words. The example, Hitler was a real coward. You are well-educated because you pursued your studies up to grade five. Irony is often confused with satire and sarcasm, but it can be used with either a satirical or sarcastic intent [10].

\section{METHOD}

As a research method, the researcher applied qualitative-descriptive as the research data approach in this study because the researcher will analyze the data in the form of words descriptively. Therefore, the qualitative is the appropriate method to complete this research because the researcher did not use the numeric or statistic form in data analysis. Qualitative research is used to describe and to analyze what usually happens in daily activities and it does not deal with number as a data [19]. In addition, descriptive research is used to obtain information about existing conditions. Moreover, it has been widely used in educational research.

The aim of this research is to investigate the types of figures of speech on political headline: Waspada and SIB newspaper. The data of this study is word or phrase in sentence from political headline on newspaper. The source of data of this study there are two newspaper they are Waspada and Sinar Indonesia Baru daily newspaper. The data would be taken from newspaper on January March 2021. This study was conducted by analysis word or phrase which were used in political headline of Waspada and Sinar Indonesia Baru (SIB) newspaper.

The qualitative research is an inquiring the process of understanding a social or a human problem based on the building a complex, holistic picture, formed of the words, reporting the detail view of informants and conducted in a natural setting. Qualitative research can be divided into some types; they are ethnography, narrative, phenomenology, grounded theory, and case study.

\section{RESULT AND DISCUSSION}

The result of the analysis in this study was discussed in accordance with the theory of the types of figures of speech, and based on political headline on the both newspapers below the table:

Table 1. Types of Figures of Speech

\begin{tabular}{llcccc}
\hline & & \multicolumn{3}{c}{ Newspaper } \\
\cline { 3 - 6 } No & $\begin{array}{c}\text { Types of figures } \\
\text { of speech }\end{array}$ & \multicolumn{2}{c}{ Waspada } & \multicolumn{2}{c}{$\begin{array}{c}\text { Sinar Indonesia } \\
\text { Baru }\end{array}$} \\
\cline { 3 - 6 } & & $\begin{array}{c}\text { Num } \\
\text { ber }\end{array}$ & $\begin{array}{c}\text { Percen } \\
\text { tage }\end{array}$ & $\begin{array}{c}\text { Numb } \\
\text { er }\end{array}$ & $\begin{array}{c}\text { Percent } \\
\text { age }\end{array}$ \\
\hline 1 & Metaphor & - & - & - & - \\
2 & Simile & - & - & - & - \\
\hline
\end{tabular}

\begin{tabular}{llcccc}
\hline 3 & $\begin{array}{l}\text { Personificati } \\
\text { on }\end{array}$ & 1 & 8.3 & - & - \\
4 & Apostrophe & - & - & 2 & 16.7 \\
5 & Metonymy & - & - & - & - \\
6 & Symbol & 5 & 41.7 & 6 & 50 \\
7 & Synecdoche & - & - & 1 & 8.3 \\
8 & Allegory & - & - & - & - \\
9 & Paradox & 2 & 16.7 & - & - \\
10 & Hyperbole & - & - & 3 & 25 \\
11 & Litotes & - & - & - & - \\
12 & Irony & 4 & 33.3 & - & - \\
& TOTAL & $\mathbf{1 2}$ & $\mathbf{1 0 0 \%}$ & $\mathbf{1 2}$ & $\mathbf{1 0 0 \%}$ \\
\hline
\end{tabular}

There were 7 out of 12 types of figures of speech were found in political headline of Waspada and Sinar Indonesia Baru newspaper. The figures of speech covered symbol, hyperbole, irony, apostrophe, synecdoche, paradox and personification. The most dominant figures of speech in Waspada and SIB was symbol. It can be found in the two newspapers but the most was applied in Sinar Indonesia Baru newspaper.

The reason why symbol is more dominant is due to the fact that the language style in the two newspapers uses a figure of speech that describes something concrete (like a person, object, image, word or event) that stands for something abstract or invisible. Basically, in both newspapers, each political headline has different types of figures of speech, but the researcher concludes only a few based on the percentage in the data. In addition, based on the ideology the two newspapers, Waspada be wary of choosing a more formal language style than the Sinar Indonesia Baru newspaper. Therefore, in the SIB newspaper there are many types of figures of speech, where the figures of speech that are often found are symbol, hyperbole, satire, euphemism, and so on. A symbol occurs when a word which has meaning in itself is used to represent something entirely different. The word can be seen with the eye or not visible. Symbol has a function in the two newspaper that is affording imaginative pleasure to the readers.

There are numerous studies related to figures of speech along with the types and functions. The first research question of this study dealt with the types of figures of speech on political headline: Waspada and Sinar Indonesia Baru (SIB) newspaper, as [15] classified there are 12 types of figures of speech, they are metaphor, simile, personification, apostrophe, metonymy, symbol, synecdoche, allegory, paradox, hyperbole, litotes and irony. And those types mentioned were conducted in analyzing the data in this research; it has been revealed there are 7 types of figures of speech found in Waspada and Sinar Indonesia Baru newspaper which have been classified into the types. And the result showed that the most headline politic in this both newspapers of types of figures of speech in this research is symbol and this 
research found some words or phrase in symbol, i.e., pasang badan, balik modal, unjuk gigi, politik praktis, dihukum mati, berita bohong, adem ayem, and so on.

The researcher concluded is the use of figures of speech can be risky since not all the readers have an ability to interpret them. Thus, there could be a misinterpretation. Yet, for the people who can interpret the figures of speech well, it could be very helpful since they can grasp the hidden meaning of the figures of speech by the source person in newspaper or the other source or article. Moreover, the functions of figures of speech are also fulfilled.

\section{CONCLUSION}

There were 7 out of 12 types of figures of speech were found in political headline of Waspada and Sinar Indonesia Baru newspaper. The figures of speech covered symbol, hyperbole, irony, apostrophe, synecdoche, paradox and personification. The most dominant figures of speech in Waspada were symbol and the most dominant figures of speech in SIB was symbol. It can be found in the two newspapers but the most was applied in Sinar Indonesia Baru newspaper.

\section{ACKNOWLEDGMENTS}

Praise God Almighty, for the presence of plenty of mercy and his grace, so that the researcher can complete the paper with the title: Figures of Speech on Political Headline: Waspada and Sinar Indonesia Baru Newspaper. This is to meet one of the conditions and completed studies in submitted to the English Applied Linguistic Study Program in Partial Fulfilment of the Requirements for the Degree of Magister Linguistic. Appreciation and thanks to the sincere beloved mother and a beloved brother who have put all our love and affection and attention to moral as well as material. May Allah SWT always bestow grace, health, gifts and blessings in the world and in the hereafter over good that has been given to the author.

Appreciation and special gratitude to the honourable advisor I, Prof I Wy Dirgeyasa, M. Hum and the honourable advisor II, Dr. Anni Holila Pulungan, M. Hum who have helped this paper writing, and Dr. Rahmad Husein, M. Ed as the head of English Applied Linguistic Study Program.

\section{REFERENCES}

[1] Al-Qudsy, and Bilal. (2016). A Stylistic Analysis of Figures of Speech in The Jakarta Post Headlines under The Issue of KPK Vs. POLRI. Faculty of Languages and Arts Yogyakarta State University

[2] Bukhari, R. J and T. Asgher (2017). "An Investigation into Stylistic Devices in Emily Dickinson's and Sylvia Plath's Poetry." International Journal of English Linguistics; Vol. 7 , No. 4; 2017.
[3] Gautam, A.K. (2014). Colletotrichum gloeosporioides: Biology, Pathogenicity and management in India. Journal of Plant Physiology and Pathology 2(2): 1-11.

[4] Glucksberg, S. (2001). Understanding Figurative Language from Metaphors to Idioms. New York: Oxford University Press.

[5] Kennedy, X. J. and Gioia. D. (2007). Literature: An Introduction to Fiction, Poetry, Drama, and Writing (10th Ed). New York: Pearson Longman.

[6] Keraf, G. (2004). Diksi dan Gaya Bahasa. Jakarta: PT. Gramedia Pustaka Utama.

[7] Khairani, D. (2017). “A Stylistic Analysis of Abdur's Stand Up Comedy in Stand-Up Comedy Indonesia (Suci) 4." Faculty Of Humanities Diponegoro University. Semarang.

[8] Khan, A. B., Batool, S., M. A. Sandhu., M. Ahmed and S. Bato. (2014). "Stylistic Analysis of William Blake's Poem: Night." Journal of ELT and Applied Linguistics (JELTAL), Vol. 2, No. 4, pp. 95-98.

[9] Leech, G., and M. Short. (2007). Style in fiction. A linguistic introduction to English fictional prose. United Kingdom: Pearson Education Limited.

[10] McArthur, T. (1992). The Oxford Companion to the English Language. Oxford and New York: Oxford University Press.

[11] Miles, M., B, Huberman, A. M. and Saldana, J. (2014). Qualitative Data Analysis-A Sourcebook of New Methods, Beverly Hill: SAGE Publisher.

[12] Mozuraityte, R. (2015). Newspaper style: Stylistic features of the headline. An

Unpublished B.A. thesis, University of Siauliai. Lithuania.

[13] Olugbenga, A.S. (2020). “A Linguistics-Stylistic Analysis of Newspaper Headlines of Mettle Attack on Nigerian Army by Boko Haram Insurgents." International Journal of Scientific and Research Publications, Volume 10, Issue 2, February 2020.

[14] Pam. (2012). “An International Journal of Language, Literature and Gender Studies Bahir Dar, Ethiopia." AFRREV LALIGENS, Vol. 1 (1) March, 2012:52-64.

[15] Perrine, L. (1992). Sound and Sense: An Introduction to Poetry (3rd Ed). New York: Harcourt, Brace \& World

[16] Praskova, E. (2009). Grammar in Newspaper Headlines. An unpublished B.A. thesis. Czech Republic: University of Pardubica

[17] Reah, D. (2002). The Language of Newspaper Headlines. London; Routledge.

[18] Safitri, R., dan R. N. Rosa. (2018). "Analysis of Syntactical Stylistic Devices on Poems in Hello 
Magazine." E-Journal of English Language and

Literature Volume 7 No. 4

[19] Saldana, J. (2011). Fundamentals of qualitative research. Oxford University Press.

[20] Simpson, P. (2011). Stylistics: A Resource Book for Students. London: Routledge 